Uşak Üniversitesi Sosyal Bilimler Dergisi

$2014,7 / 4$

\title{
Sınıf Öğretmenlerinin Mesleki Gelişim Eğitimlerine İlişkin Genel Görüşlerinin Belirlenmesi*
}

\author{
Mukadder BOYDAK ÖZAN** \\ Gönül ŞENER ${ }^{* * *}$ \\ Hakan POLAT ${ }^{* * * * *}$
}

Özet

Toplum olarak ilerlemek ve gelişmiş ülkelerin refah düzeyine ulaşmak, okullarda iyi bir eğitimin verilmesiyle mümkün olur. Okullarda verilen eğitimin niteliğinin arttırılması, öğretmenlerin niteliğinin arttırılması ile sağlanır. Bu çalışma ile ilkokullarda ders yılı başında ve ders yılı sonunda olmak üzere yılda iki defa yapılan mesleki gelişim eğitimleri (seminer çalışmaları) hakkında sınıf öğretmenlerinin genel görüşlerinin belirlemesi amaçlanmaktadır. Bu amaçla hazırlanan dört adet açık uçlu soru görüşleri alınmak üzere rastgele yöntemle seçilmiş 60 öğretmene sorulmuştur. Elde edilen verilerin analizinde nitel araştırmaların çözümlenmesinde kullanılan içerik analiz yöntemi kullanılmıştır. Araştırmanın sonucunda öğretmenler, mesleki gelişim eğitimi kapsamında yürütülen çalışmaların amacını; yenilikleri takip etmek, haberdar etmek ve eksiklikleri gidermek olarak belirlerken, öğretmenlerin birçoğu bu çalışmalarının kendilerine katkı sağlamadığını düşünmektedir. Öğretmenler zaman açısından mesleki gelişim çalışmalarının şimdi olduğu gibi sene başı ve sene sonunda olmak üzere yılda iki defa yapılmasının ya da süreç içine yayılarak yapılmasının daha uygun olacağını belirtmişlerdir. Ayrıca öğretmenler, mesleki gelişim eğitimlerinde, ilgi ve ihtiyaçlarının dikkate alınması, çalışmaların uygulamaya dönük olması ve alanında uzman kişilerin bu çalışmalarda görev almasının etkililik açısından fayda sağlayacağını düşünmektedirler. İlkokul.

Anahtar Kelimeler: Mesleki Gelişim Eğitimi, Sınıf Öğretmeni,

\footnotetext{
* Bu çalışma “Uluslararası Öğretmen Eğitiminde Yeni Yönelimler” Konferansında bildiri olarak sunulmuştur.

${ }^{* *}$ Doç. Dr., Fırat Üniversitesi, Eğitim Bilimler Bölümü, Eğitim Yönetimi, Teftişi, Planlaması ve Ekonomisi Anabilim Dalı

${ }^{* * *}$ Doktora Öğrencisi, Firat Üniversitesi, Eğitim Bilimleri Enstitüsü, Eğitim Yönetimi, Teftişi, Planlaması ve Ekonomisi Anabilim Dalı

Okutman Fırat Üniversitesi, Enformatik Bölümü
} 


\title{
Determination of the General Views of Class Teachers Regarding Their Career Development Training
}

\begin{abstract}
Advancing as a society and reaching the level of welfare of developed countries are only possible by offering good education in schools. The quality of the education offered in schools is increased by means of increasing the qualifications of the teachers. With this study, it is aimed to determine the general views of class teachers on their career development training (seminar works) held twice a year, one of them being at the beginning and the other at the end of the school year for primary schools. Four open-ended questions prepared to this end were asked to 60 teachers chosen randomly to take their views. Content analysis method used for the analysis of qualitative researches was used in the analysis of the data obtained. As a result of the research, while the teachers establish the studies carried out within the scope of career development training as keeping up with the novelties, informing and overcoming the deficiencies, most of the teachers think that this training does not contribute to them. The teachers stated that in terms of the time, it would be appropriate to carry out the career development courses twice a year, one of them being at the beginning and the other at the end of the school year, as it they are now or extending them over the process. Furthermore, the teachers think that it would be beneficial in terms of effectiveness of the career development training to take into account the interests and needs, that the courses are application based and experts in their fields take part in the courses.
\end{abstract}

Key Words: Career Development Training, Class Teacher, Primary School.

\section{Giriş}

Günümüzde bilim ve teknolojide yaşanan hızlı gelişmeler, sosyal, ekonomik ve kültürel alanlarda önemli değişimlere yol açmaktadır. Bireyler yaşanılan bu değişimlere ayak uydurmak ve yenilikleri takip edebilmek için yaşam boyu öğrenmeye ihtiyaç duymaktadır. Sosyal bir sistem olan eğitim bireylerin bu ihtiyacını karşılayarak, toplumdaki yeni bilgi ve becerileri bireye kazandırmak yoluyla, onların toplumun değişen koşullarına uyum sağlamasını kolaylaştırmaktadır (Taymaz, 1992). Özellikle çalışma yaşamında bireylerin mesleki gelişimleri için hazırlanan eğitimler 
çalışanlara mesleklerinde daha başarılı, üretici ve mutlu olmasını sağlayacak bilgi, beceri ve tutumlar kazandırmayı amaçlamaktadır (Yalın, 2001).

Örgütlenmiş bütün etkinlikler içinde insanın en önemli olduğu alan eğitimdir. Eğitimin en etkin insan unsurunu ise öğretmenler oluşturmaktadır (Kayabaş, 2008). Toplumun geleceği olan bireyleri yetiştiren öğretmenlerin üstendiği sorumluluklarını en iyi şekilde yerine getirmeleri için sürekli olarak kendilerini yenilemesi ve geliştirmesi gerekmektedir. Fullan ve Pomfret, öğretmenlerin mesleki gelişimi ile yenilikçiliğin birbiriyle bağlantılı olduğunu vurgulayarak, okullarda yaşanan değişim için öğretmenlerin gelişiminin önemli olduğuna dikkat çekmiştir (akt: Yılmaz ve Kocasaraç, 2010).

Öğretmenlerin hizmet öncesinde aldığı eğitim üç beş yıl içinde güncelliğini yitirmektedir. Dolayısıyla öğretmenlerin var olan bilgileriyle mesleğini gereği gibi yürütmesi zorlaşmaktadır. Bu nedenle öğretmenlerin, eğitimle ilgili yayınlardan, mesleki seminer çalışmalarından, hizmet içi seminerlerden, internet ve diğer her türlü imkânlardan yararlanması, mesleği ile ilgili yenilikleri ve gelişmeleri takip etmesi, meslek hayatı boyunca bilgilerini yenilemesi, kendini yetiştirmesi, çağın insanını hazırlaması açısından zorunludur (MEB, 2006).

Saban (2000), öğretmenlerin hizmet içi eğitime tabi tutulmasını gerekli kılan başlıca nedenleri şöyle sıralamaktadır:

$\checkmark$ Bilimdeki değişmeler,

$\checkmark$ Toplumsal değişimeler,

$\checkmark$ Okul sistemlerindeki değişmeler,

$\checkmark$ Öğretmenlerin kendi ilgi alanlarındaki değişmeler,

$\checkmark$ Öğretim yöntemleri ve teknolojisi alanındaki yeni gelişmeler.

Öğretmenlere yönelik hizmet içi çalışmaların, öğretmenlerin ihtiyaçlarına dayalı olarak gerçekleşmesi beklenmektedir. Roux ve Fereira, (2005) öğretmenlerin aşağıdaki konularda hizmet içi eğitimden geçirilmeleri gerektiğini belirtmektedir:

$\checkmark$ Var olan ya da yeni politikaların öğretmenlere tanıtılması gibi politik konular,

$\checkmark$ Okulun nüfusu, yönetimi ve vizyonundaki değişiklikler gibi içerikle ilgili konular,

$\checkmark$ Öğretim, konu alanı ya da sunum becerilerini geliştirme gibi mesleki bilgi ve becerilerle ilgili konular,

$\checkmark$ Bireysel ya da grup performansını artırmayı amaçlayan performansa dayalı konular ve kariyer gelişimine yönelik konular.

Houston (1990), hizmet içi öğretmen eğitimlerinin konferanslar, seminerler ve formal dersler gibi birçok etkinlik yoluyla 
gerçekleştirilebileceğini ve bu türdeki faaliyetlerin öğretmenlerin mesleki bilgi ve becerilerinin geliştirilmesi ve sürdürülmesini sağladığını belirtmektedir.

İlköğretim Kurumları Yönetmeliği'nde ise, “Hizmet içi eğitim faaliyetleri kapsamında yürütülen mesleki gelişim eğitimlerine ilişkin, ilköğretim kurumlarında görevli yönetici ve öğretmenlerin genel kültür, özel alan eğitimi ve pedagojik formasyon alanlarında, bilgi ve görgülerini artırmak, yeni beceriler kazandırmak, eğitim ve öğretimde karşılaşılan problemlere çözüm yolları bulmak, öğrencinin ve çevrenin ihtiyaçlarına göre plan ve programları hazırlamak ve uygulamak amacıyla derslerin kesiminden temmuz ayının ilk işgününe, eylül ayının ilk işgününden derslerin başlangıcına kadar; yıl içinde ise yıllık çalışma programında belirtilen sürelerde meslekî çalışma yapılır" (2013) maddesi yer almaktadır. $\mathrm{Bu}$ madde gereğince yürütülen mesleki gelişim eğitimlerinde yönetici ve öğretmenler (İKY, 2013):

a) İlköğretim ders programlarında, mevzuatında ve uygulamalarında yapılan değişiklikleri inceler ve değerlendirir.

b) Birbiri ile ilişkili alanlarda zümre öğretmenleri iş birliği yapar.

c) Yeni öğretim yılında uygulayacakları yıllık çalışma programları, iş takvimini planlar ve iş bölümü gibi hazırlıkları yapar.

d) Kayıt işlemleri ile ilgili olarak veli görüşmelerini gerçekleştirir.

Bu çalışma ile ilkokullarda ders yılı başında ve ders yılı sonunda olmak üzere yılda iki defa yapılan mesleki gelişim eğitimleri (seminer çalışmaları) hakkında sınıf öğretmenlerinin genel görüşlerinin belirlemesi amaçlanmaktadır. Bu amaç çerçevesinde aşağıdaki sorulara yanıt aranmıştır:

1) Mesleki gelişim eğitimlerinin amacı ne olmalıdır?

2) Mesleki gelişim eğitimlerinin yararları nelerdir?

3) Mesleki gelişim eğitimleri ne zaman yapılmalıdır?

4) Mesleki gelişim eğitimlerinin daha etkili bir şekilde yapılmasına yönelik görüşleriniz nelerdir?

\section{Yöntem}

\section{Araştırmanın Modeli}

Sınıf öğretmenlerinin mesleki gelişim eğitimlerine ilişkin genel görüşlerinin belirlenmeye çalışıldığ 1 bu araştırmada, nitel araştırma yöntemlerinden olgubilim "fenomology" deseni kullanılmıştır. Olgubilim deseni, farkında olduğumuz ancak derinlemesine ve ayrıntılı bir anlayışa sahip olmadığımız olgulara odaklanır. Olgubilim bize tamamen yabancı 
olmayan ancak tam olarak anlamını kavrayamadığımız olguları araştırmada uygun bir yöntemdir (Yıldırım ve Şimşek, 2011:72).

\section{Çalışma Grubu}

Araştırmanın çalışma grubunu 2012-2013 eğitim-öğretim yılında Elazığ il merkezinde görev yapan 60 öğretmen oluşturmaktadır. Bu araştırmada tesadüfi ve orantısız küme örnekleme yöntemi kullanılarak çalışma grubu belirlenmiştir. Buna göre Elazı̆̆ il merkezinde yer alan okullar rasgele yöntemle listeden seçilmiş ve seçilen bu okullarda görev yapan öğretmenler örneklem olarak belirlenmiştir. Küme örnekleme çalışılması düşünülen evrende doğal olarak oluşmuş veya farklı amaçlarla yapay olarak oluşturulmuş, kendi içinde belirli özellikler açısından benzerlik gösteren değişik grupların olması durumunda kullanılmaktadır (Yıldırım, Şimşek, 2011:105).

\section{Veri Toplama Aracı}

Mesleki gelişim eğitimlerine ilişkin sınıf öğretmenlerinin genel görüşlerini belirlemeye yönelik olarak hazırlanan dört adet açık uçlu soru görüşleri alınmak üzere öğretmenlere sorulmuştur. Soruların hazırlanmasında, literatürdeki mevcut çalışmalar incelenmiş ve üç uzman görüşü alınmıştır. Sınıf öğretmenlerine, görüşme formları verilerek, gerekli açıklamalar yapılmış bu formları doldurup teslim etmeleri istenmiştir. Doldurulan bu görüşme formları araştırmanın temel veri kaynağı olarak kabul edilmiştir.

\section{Verilerin Analizi}

Sınıf öğretmenlerinin görüşleri dikkate alınarak elde edilen verilerin analizinde nitel araştırmaların çözümlemesinde kullanılan "içerik analizi" yöntemi kullanılmıştır. İçerik analizinde, temelde yapılan işlem, birbirine benzeyen verileri belirli kavramlar ve temalar çerçevesinde bir araya getirmek ve bunu okuyucunun anlayabileceği bir biçimde organize ederek yorumlamaktır. İçerik analizinde temel amaç, toplanan verileri açıklayabilecek kavramlara ve ilişkilere ulaşmaktır. Bu yolla veriler tanımlanmaya, verilerin içinde saklı olabilecek gerçekler ortaya çıkarılmaya çalışılır (Yıldırım, Şimşek, 2011:227). Çalışmada ilk olarak öğretmenlerin görüşme formuna vermiş oldukları yanıtlar incelenmiş ve öğretmenlerden toplanan bütün veriler (60 görüşme formu) geçerli kabul edilmiştir. Daha sonra bu anketler üzerinde çözümlemeler yapılmıştır. 60 anketin her birine sırayla sayı numarası verilerek her bir soru için bir Word belgesi oluşturulmuş ve yanıtlar istatistiksel veri analiz programında analiz edilmiştir. Öğretmenlerin görüşlerinin analizinde, ifadelerin benzerliğine göre gruplandırmalar yapılarak temalar oluşturulmuş ve görüşler uygun temalara yerleştirilmiştir. Ayrıca çalışmada öğretmenlerin görüşlerine ilişkin 
frekans değerleri belirlenmiştir. Her bir temada dikkat çeken katılımcı görüşlerine doğrudan alıntılarla yer verilmiştir. Araştırmanın güvenirliliğini ölçmek için, öğretmen görüşlerinden elde edilen dört farklı soruya vermiş oldukları yanıtların yerleştirildiği temayı temsil edip etmediğini görebilme amaciyla uzman görüşüne başvurulmuştur. Bu doğrultuda uzman tarafından incelenmesi istenen soru formlarından elde edilen yanitlar ile araştırmacı tarafından oluşturulan tema listesi, hiç bir yanıt dışarıda kalmayacak şekilde eşleştirmesi yapılmıştır. Ayrıca araştırmanın güvenilirliğini ölçmek için Miles ve Heberman'ın geliştirdiği Uzlaşma Yüzdesi $(\mathrm{P})=$ Görüş Birliği $(\mathrm{Na}) /($ Görüş Birliği $(\mathrm{Na})+$ Görüş Ayrıllğı $(\mathrm{Nd})) X$ 100 formülü kullanılmıştır. Nitel çalışmalarda, uzman ve araştırmacı değerlendirmeleri arasındaki uyumun $\% 90$ ve üzeri olduğu durumlarda güvenirlik sağlanmış olmaktadır (Saban, 2008:467). Buna göre görüşüne başvurulan uzman sadece altı ifadeyi araştırmacılardan farklı bir kategoriyle yerleştirmiştir. Bu hesaplamanın ardından araştırmanın güvenirliği; $\mathrm{P}=282$ / $(282+6) \times 100=\% 98$ olarak bulunmuştur. Bu sayede araştırmanın iç geçerliği sağlanmıştır. Araştırmanın dış geçerliğinin sağlanması için ise araştırmanın örneklemi genellemeye izin verecek şekilde seçilmiştir. Karasar (2008), varılan bir nedensel ilişkide, sonuç un bilinen nedenlerle gerçekten açıklanabilirliğini iç geçerlilik olarak tanımlarken, örnek bir grup üzerinde ve araştırma koşulları içinde varılan bir sonucun, gerçek yaşama genellenebilirliğini de dış geçerlilik olarak tanımlamıştır.

\section{Bulgular}

Sınıf öğretmenlerine sorulan "Mesleki gelişim eğitimlerinin amacı ne olmalıdır?" sorusuna ilişkin öğretmenlerin vermiş oldukları yanıtlar incelenmiştir. Mesleki gelişim eğitimlerine ilişkin oluşturulan ana temalar, ana temalara bağlı kategoriler ve frekans değerleri Şekil 1'de verilmiştir. 


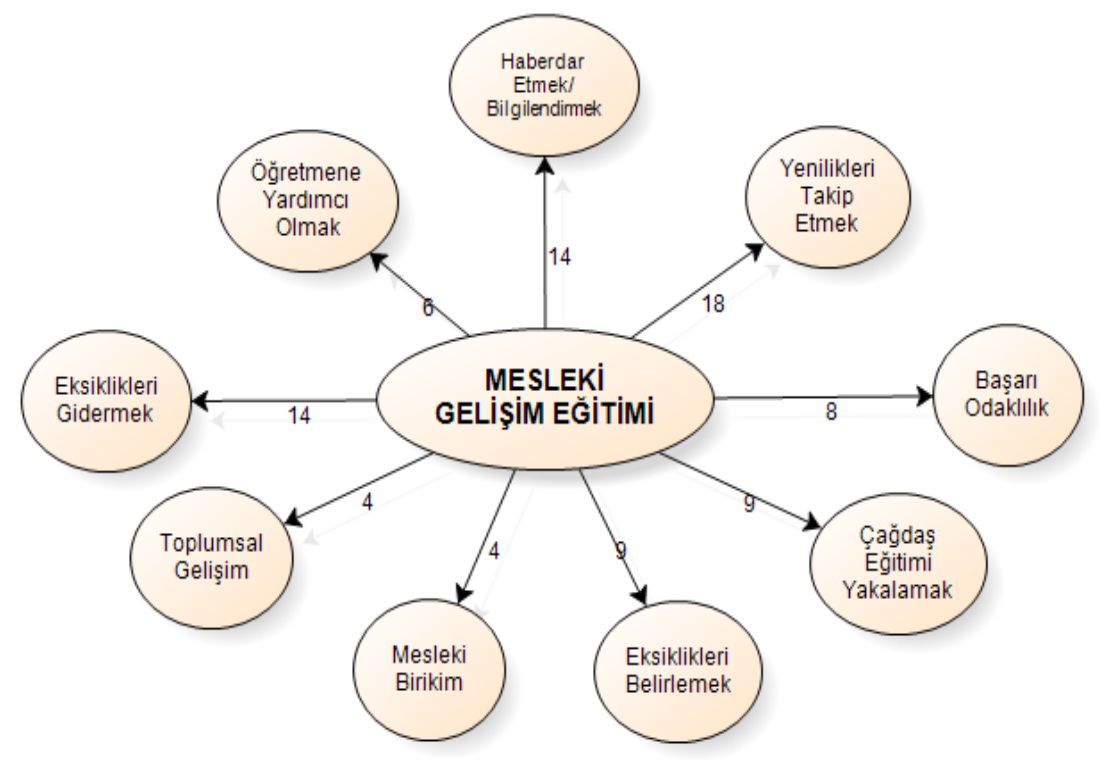

Şekil 1: Mesleki Gelişim Eğitiminin Amacı

Sınıf öğretmenleri, mesleki gelişim eğitimlerinin daha çok yenilikleri takip etmek $(\mathrm{f}=18)$, haberdar etmek/bilgilendirmek ( $\mathrm{f}=14)$ ve eksiklikleri gidermek ( $\mathrm{f}=14)$ amacına yönelik olarak yapılması gerektiği yönünde görüş bildirmişlerdir. Mesleki birikim ( $\mathrm{f}=4)$ ve toplumsal gelişim $(\mathrm{f}=4)$ amaciyla yapılması yönünde daha az öğretmen görüşlerine rastlanmıştır.

Öğretmenlerin mesleki gelişim eğitimlerinin amacına ilişkin görüşleri ile ilgili örnek ifadelere aşağıda yer almaktadır:

- Meslekte yenilikleri takip edip başarıyı artırmak, verimi artırmak olmalıdır.

- Bilimsel ve çă̆a uygun olmalıdır.

- Kişiyi kendi mesleği ile ilgili bilgilendirmek ve eksikliklerin giderilmesi olmalidır.

- Mesleki çalışmaların amacı yeni gelişmelerden öğretmenleri haberdar etmek olmalidır.

- Amacı gelişim sağlamak ve yenilikleri öğrenmek olmalıdır.

"Mesleki gelişim eğitimlerinin yararları nelerdir?" sorusuna ilişkin olarak, öğretmen görüşleri dikkate alındığında oluşturulan ana temalar, ana temalara bağlı kategoriler ve frekans değerleri Şekil 2' de gibi gösterilmiştir. 


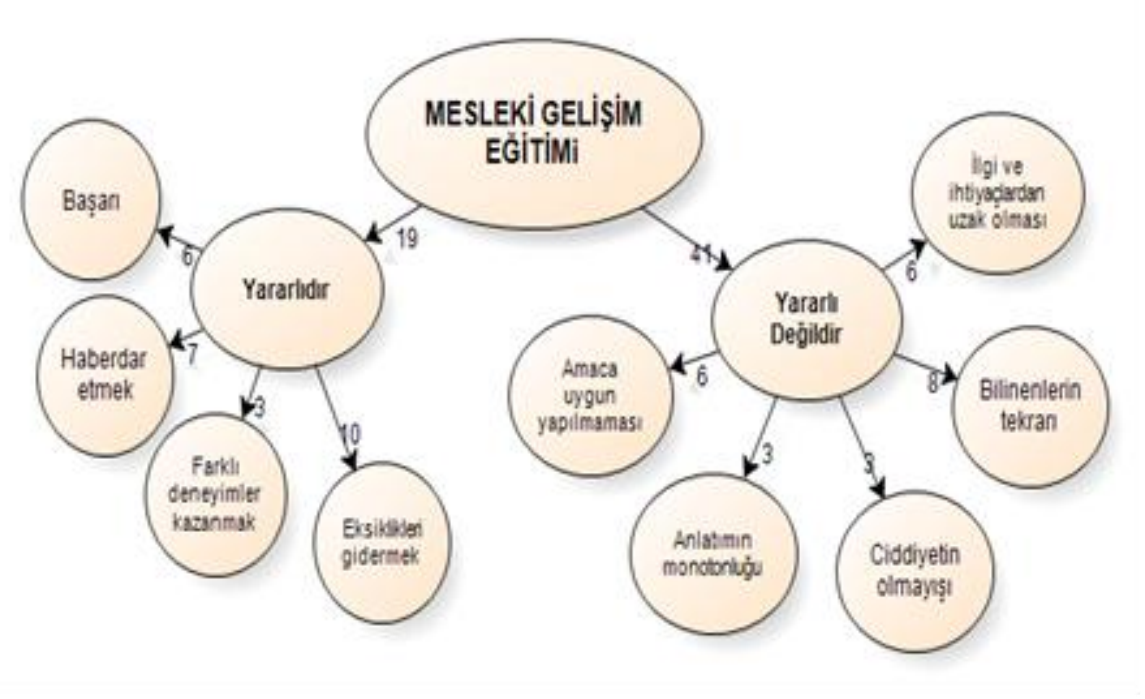

Şekil 2: Mesleki Gelişim Eğitimlerinin Yararları

Elde edilen verilere göre yapılan mesleki gelişim eğitimlerinin yararlı olduğunu düşünen öğretmenlerin yanında, yararlı olmadığını düşünen öğretmen görüşleri de yer almaktadır. Bu eğitimlerin yararlı olmadığını düşünen öğretmenlerin $(\mathrm{f}=41)$, yararlı olduğunu düşünen öğretmenlere göre daha fazla olması dikkat çekicidir. Mesleki gelişim eğitimlerinin yararlı olmadığını düşünen öğretmenler bunun gerekçesi olarak bilinenlerin tekrarı olması $(\mathrm{f}=8)$, ilgi ve ihtiyaçlardan uzak olması $(\mathrm{f}=6)$ ve amaca uygun olarak yapılmadığını $(f=6)$ ileri sürmüşlerdir. Bunun yanında öğretmenler bu eğitimlerin eksiklikleri gidermek $(\mathrm{f}=10)$ ve haberdar etmek ( $\mathrm{f}=7$ ) konularında yararlı olduğunu öne sürmüşlerdir.

Öğretmenlerin mesleki gelişim eğitimlerinin yararlarına ilişkin görüşleri ile ilgili örnek ifadeler aşağıda verilmiştir:

$\checkmark$ Amaca uygun olarak yapılan mesleki çalışmalar uygun olur. Ancak bugüne kadar yapılan mesleki çalışmalar öğretmenlerin mesleki bilgilerini geliştirmeye yönelik olmamıştır.

$\checkmark$ Bildiğim ve uyguladığım yöntem ve teknikleri bana aktarmaktan başka bir kazanımı yoktur.

$\checkmark$ İlgim ve ihtiyacım doğrultusunda slradanlıktan uzak ve gerçekçi eğitim çalışmalarm istiyorum. 
$\checkmark$ Eğitimdeki mesleki çalışmalar unutulan bazı bilgi ve kuramların yeniden hatılanması ve yeni gelişmelerden haberdar olmamı bakımından önemlidir.

$\checkmark$ Her yıl yenilenen yönetmelikler, eğitim programlan, eğitim yöntemleri hakkında katkı sağlamaktadır.

“Mesleki gelişim eğitimleri ne zaman yapılmalıdır?" sorusuna ait sınıf öğretmenlerinin mesleki gelişim eğitiminin zamanı hakkındaki görüşlerine ilişkin oluşturulan ana temalar, ana temalara bağlı kategoriler ve frekans değerleri Şekil 3’teki gibi gösterilmiştir.

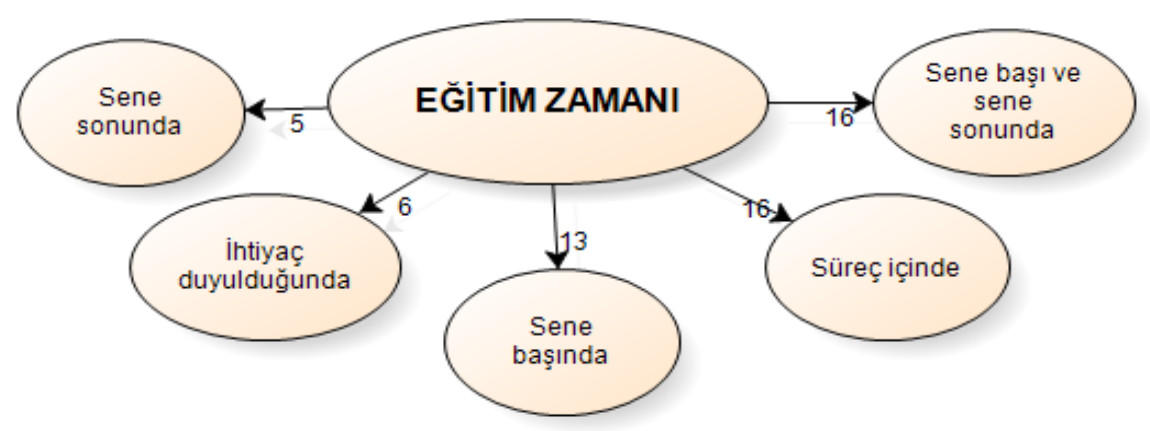

Şekil 3: Mesleki Gelişim Eğitimine İlişkin Zamanlama

Mesleki gelişim eğitimlerine ilişkin en uygun zamanın sene başında ve sene sonunda $(\mathrm{f}=16)$ ya da devam eden eğitim süreci içinde ( $\mathrm{f}=16)$ yapılmasına yönelik öğretmen görüşlerinin daha sık tekrarlandığ 1 görülmüştür. Bu bulguya göre öğretmenler mesleki gelişim eğitimlerinin şimdi olduğu gibi sene başı ve sene sonunda yapılmasının ya da süreç içine yayılarak yapılmasının daha faydalı olacağını düşünmektedirler. Bunun yanında sadece sene sonunda $(\mathrm{f}=5)$ ve ihtiyaç duyulduğunda $(\mathrm{f}=6)$ yapılması gerektiğini düşünen öğretmen görüşleri de yer almaktadır.

Öğretmenlerin mesleki gelişim eğitimlerinin zamanlamasına ilişkin görüşleri ile ilgili örnek ifadeler aşağıda verilmiştir:

$\checkmark \quad S$ u anda uygulanan tarihlerin yerinde olduğ kanaatindeyim.

$\checkmark$ Yılsonu ve öğretim başında yapılması yararlı olur.

$\checkmark$ Tüm yıla yayılmalıdır.

$\checkmark \quad$ Yll içerisinde eğitim öğretimle beraber yürütülebilir.

“Mesleki gelişim eğitimlerinin daha etkili bir şekilde yapılmasına yönelik görüşleriniz nelerdir?" sorusuna ait mesleki gelişim eğitimine ilişkin öneriler hakkındaki görüşlerine ilişkin oluşturulan ana temalar, ana temalara bağlı kategoriler ve frekans değerleri Şekil 3 'teki gibi gösterilmiştir. 


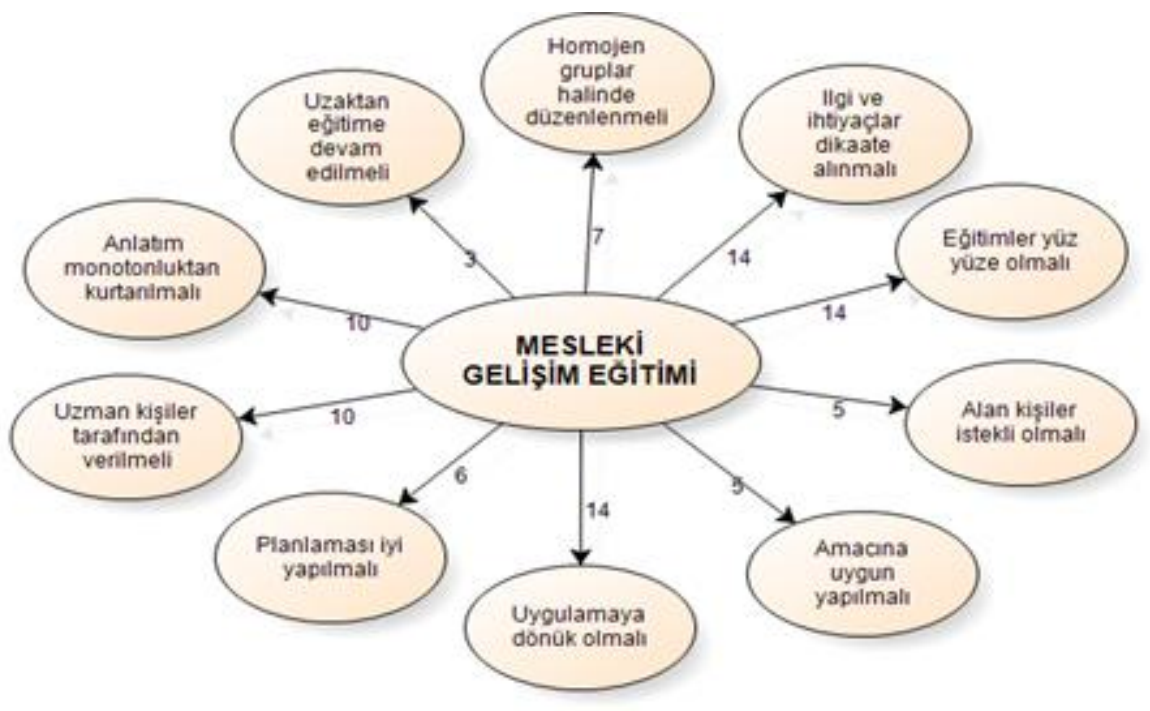

Şekil 4: Mesleki Gelişim Eğitimine İlişkin Öneriler

Öğretmenler, mesleki gelişim eğitimlerinin daha etkili bir şekilde yürütülmesi için, ilgi ve ihtiyaçların dikkate alınması ( $\mathrm{f}=14)$, eğitimlerin yüz yüze olması $(\mathrm{f}=14)$ ve eğitimlerin uygulamaya dönük olması ( $\mathrm{f}=14)$ gerektiğini ileri sürülmüştür. Öğretmenler bunun yanında anlatımının monotonluktan kurtarılması ( $\mathrm{f}=10)$, eğitimlerin uzman kişiler tarafından verilmesi ( $\mathrm{f}=10$ ) grupların homojen olarak düzenlenmesi $(\mathrm{f}=7)$, planlamanın iyi bir şekilde yapılmasının $(f=6)$ daha etkili bir eğitimin gerçekleşmesi açısından fayda sağlayacağını dile getirmişlerdir.

Öğretmenlerin mesleki gelişim eğitimlerinin daha etkili yapılmasına ilişkin görüşleri ile ilgili örnek ifadeler aşağıda verilmiştir:

$\checkmark$ Yüz yüze eğitim ile etkileşim să̆lanmalıdır.

$\checkmark$ Insanların beklentilerine cevap verecek ölçüde olmalıdır.

$\checkmark$ Birebir diyalog kurulması ve katılanlara aktif görev verilmesi daha iyi olur.

$\checkmark$ Insanları bilgisayar başına toplayarak değil, daha ilgi çekici yöntemler kullanılarak yapılmalıdir.

$\checkmark$ Mesleki eğitim, mesleki geliştirme çalışmaların konunun uzmanı olan kişiler vermelidir. 


\section{Sonuç, Tartışma ve Öneriler}

$\mathrm{Bu}$ araştırmayla ilkokullarda ders yılı başında ve ders yılı sonunda olmak üzere yılda iki defa yapılan mesleki gelişim eğitimleri (seminer çalışmaları) hakkında sınıf öğretmenlerinin genel görüşleri belirlemiştir. Sorulan dört açı uçlu soruya öğretmenlerin verdikleri yanıtlar dikkate alınarak analizler yapılmış ve elde edilen sonuçlar aşağıdaki gibi değerlendirilmiştir.

"Mesleki gelişim eğitimlerinin amacı ne olmalıdır?" sorusuna ilişkin verilen yanıtlar incelendiğinde; öğretmenler daha çok yenilikleri takip etmek, haberdar etmek/bilgilendirmek, eksiklikleri gidermek amacına yönelik olarak mesleki gelişim eğitimlerinin düzenlenmesi gerektiği yönünde görüş bildirmişlerdir. Kayabaş (2008) yapmış olduğu çalışmada, hizmet-içi eğitim uygulamalarının temel amacının öğretmenlerin gelişiminin sağlanması, alanındaki yenilik ve gelişmelerden haberdar edilmesi olduğunu vurgulamıştır. Bu sonuç araştırmadan elde edilen sonuçları destekler niteliktedir. Ayrıca öğretmen mesleki birikim ve toplumsal gelişim temalarına ilişkin ifadelerin daha az tekrarlandığı elde edilen sonuçlar arasındadır.

Mesleki gelişim eğitimlerinin yararlı olmadığını düşünen öğretmenlerin, yararlı olduğunu düşünen öğretmenlere göre daha fazla olduğu dikkat çekicidir. Bu eğitimlerin yararlı olmadığını düşünen öğretmenler bunun gerekçesi olarak bilinenlerin tekrarı olması, ilgi ve ihtiyaçlardan uzak olması ve amaca uygun olarak yapılmadığını ileri sürmüşlerdir. Bu sonuç Madden'in (2003) araştırmasında, hizmet içi eğitim etkinliklerinin okul yöneticileri ve öğretmenlerin eğitim programlarında amaçlanan bilgileri kısmen kazanabildikleri, kazandıkları bilgileri ise iş yaşamlarında istenen düzeyde kullanamadıkları yönünde ulaştığı sonuç ile örtüşmektedir. Buna karşın Gültekin ve Çubukçu'nun (2008) ilköğretim öğretmenlerinin hizmet içi eğitime ilişkin görüş ve önerilerini ortaya koymak amacıyla yaptıkları çalışmada, ilköğretim öğretmenlerinin hizmet içi eğitimi gerek kurumsal gerekse bireysel bakımdan kendilerine katkı getiren bir etkinlik olarak gördüklerini belirlemişlerdir. Bu çalışmada mesleki gelişim eğitimlerinin yararlı olduğunu düşünen öğretmenler bu yararın eksiklikleri giderme ve haberdar etme konusunda olduğunu bildirmişlerdir.

Mesleki gelişim eğitimlerine ilişkin en uygun zamanın hem sene başında hem de sene sonunda ya da süreç içinde yapılmasına yönelik öğretmen görüsslerinin daha sık tekrarlandığı görülmüştür. Bu bulguya göre öğretmenler mesleki gelişim eğitimlerinin şimdi olduğu gibi sene başı ve 
sene sonunda yapılmasının ya da süreç içine yayılarak yapılmasının daha faydalı olacağını düşünmektedir. Bunun yanında sadece sene sonunda ve ihtiyaç duyulduğunda bu eğitimlerin yapılması gerektiğini düşünen öğretmen görüşlerine daha az rastlanmıştır.

Öğretmenler, mesleki gelişim eğitimlerinin daha etkili bir şekilde yürütülmesi için ilgi ve ihtiyaçlar dikkate alınması gerektiğini, eğitimlerin yüz yüze olması gerektiği ve eğitimlerin uygulamaya dönük olması görüşlerini ileri sürmüşlerdir. $\mathrm{Bu}$ önerileri anlatımının monotonluktan kurtarılması, eğitimler uzman kişiler tarafından verilmesi gerektiği, grupların homojen olarak düzenlenmesi, planlamanın iyi bir şekilde yapılması görüşleri izlemektedir. Ekinci ve Yıldırım'ın (2009) yapmış olduğu çalışmada da katılımcılar, hizmet içi eğitim görevlerinin alanında uzman, deneyim sahibi ve meslekî bilgisi yeterli kişiler arasından seçilmesi gerektiğini belirtmişler. Ayrıca yapılan çalışmalarda mesleki gelişim etkinliklerindeki konuların öğretmenlerin gerçek ihtiyaçlarına yönelik olması ve uygulamaların izlenmesi gerektiği vurgulanmıştır (Aydoğan, 2002; Bayrakçı, 2009; Bümen vd., 2012; Demirkol, 2010; Çiftçi, 2008; Özer, 2004; MEB, 2006). Bu sonuçlar araştırmadan elde edilen sonuçlarla örtüşmektedir.

Ulaşılan sonuçlar dikkate alınarak mesleki çalışmaların bu doğrultuda yeniden gözden geçirilmesi, çalışmaların etkililiği açısından fayda sağlayacağı düşünülmektedir. Ayrıca öğretmenlerin mesleki gelişiminin daha etkili gerçekleştirilmesi için farklı ülkelerdeki uygulamalar izlenmelidir.

\section{Kaynakça}

Aydoğan, İ. (2002). MEB İlköğretim Okulları Yönetici ve Öğretmenlerinin Personel Geliştirmeye İlişkin Görüşleri (Kayseri İli Örneği), Yayımlanmamış Doktora Tezi, Ankara Üniversitesi Eğitim Bilimleri Enstitüsü, Ankara.

Bayrakçı, M. (2009). In-service Teacher Training in Japan and Turkey: A Comparative Analysis of Institutions and Practices, Australian Journal of Teacher Education, 34(1), 10-22.

Bümen, N. T., Ateş, A., Çakar, E., Ural, G., Acar, V. (2012). Türkiye Bağlamında Öğretmenlerin Mesleki Gelişimi: Sorunlar ve Öneriler, Milli Eğitim Dergisi, 194, 31-50.

Çiftçi, E. (2008). Türkiye'de Milli Eğitim Bakanlığı Tarafından Müzik Öğretmenlerine Verilen Hizmet içi Eğitimin İncelenmesi ve Müzik 
Öğretmenlerinin Hizmet içi Eğitim İhtiyaçlarının Belirlenmesi, Yayımlanmamış Doktora Tezi, Gazi Üniversitesi Eğitim Bilimleri Enstitüsü, Ankara.

Demirkol, M. (2010). İlköğretim Okullarında Öğretmenlere Yönelik OkulTemelli Hizmet İçi Eğitim Etkinliklerinin Değerlendirilmesi, Milli Ĕ̆itim Dergisi, 188, 158-173.

Ekinci, Ö. ve Yıldırım, A. (2009). İl Eğitim Denetmenleri ve İlköğretim Okulu Yöneticilerinin Hizmet İçi Eğitim Faaliyetlerine Yönelik Beklentileri, Ege Eğitim Dergisi, 10 (1), 70-91

Gültekin, M., ve Çubukçu, Z. (2008). İlköğretim Öğretmenlerinin Hizmet İçi Eğitime İlişkin Görüşler, Manas Üniversitesi Sosyal Bilimler Dergisi, 19, 185-201.

Houston, W. R. (1990). Handbook of Research on Teacher Education. A Project of the Association of Teacher Education. NY: Macmillian Publishing Company.

İlköğretim Kurumları Yönetmeliği. (2013). Mesleki Çalışmalar. Madde 98, http://mevzuat.meb.gov.tr/html/225_0.html, Erişim Tarihi: 20/06/2013.

le Roux, C. \& Ferreira, J. G. (2005). Enhancing Environmental Education Teaching Skills Through in-Service Education and Training. Journal of Education for Teaching, 31(1), 3-14.

Madden, T. (2003). Okul Yöneticileri ve Öğretmenler İçin Düzenlenen Hizmet İçi Eğitim Etkinliklerinin Değerlendirilmesi (Eskişehir İli). Yayınlanmamış Yüksek Lisans Tezi. Anadolu Üniversitesi Eğitim Bilimleri Enstitüsü.

MEB, (2006). İlköğretim Okulu Öğretmenlerinin Yaptıkları Mesleki Seminer Çalışmalarının Değerlendirilmesi, Ankara.

Karasar, N. (2008). Bilimsel Araştırma Yöntemi (17.Baskı). Ankara: Nobel Yayın Dağıtım.

Kayabaş, Y. (2008). Öğretmenlerin Hizmet İçi Eğitimde Yetiştirilmesinin Önemi ve Esasları, Türkiye Sosyal Araştırmalar Dergisi, 12(2), 9-32.

Özer, B. (2004). In-Service Training of Teachers in Turkey at the Beginning of the 2000s, Journal of In-Service Education. 30(1), 89-100.

Saban, A. (2000). Hizmet İçi Eğitimde Yeni Yaklaşımlar, Millî Eğitim Dergisi, 145.

Saban, A. (2008). Okula İlişkin Metaforlar, Kuram ve Uygulamada Eğitim Yönetimi, 55, 459-496.

Taymaz, H. (1992). Hizmet içi Ĕ̆itim Kavramlar, İlkeler, Yöntemler. Personel Eğitimi Geliştirme Merkezi Yayınları, Ankara.

Yalın, H. İ. (2001). Hizmet İçi Eğitim Programlarının Değerlendirilmesi, Milli Ĕ̆itim Dergisi, 150. 
Yıldırım, A., Şimşek, H. (2011). Sosyal Bilimlerse Nitel Araştırma Yöntemleri, Seçkin Yayıncılık, Ankara.

Yılmaz, H., Kocasaraç, H. (2010). Hizmet içi Öğretmen Eğitiminde Yeni Bir Yaklaşım: Yenilikçi Öğretmenler Programı Ve Değerlendirmesi, Ahi Evran Üniversitesi Eğitim Fakültesi Dergisi, 11(3), 51-64. 